\title{
Rhizobium mesosinicum sp. nov., isolated from root nodules of three different legumes
}

\author{
Dong Xu Lin, ${ }^{1}+$ Wen Feng Chen, ${ }^{1} \dagger$ Feng Oin Wang, ${ }^{1,2}$ Dong Hu, ${ }^{1}$ \\ En Tao Wang, ${ }^{3}$ Xin Hua Sui ${ }^{1}$ and Wen Xin Chen ${ }^{1}$ \\ ${ }^{1}$ State Key Laboratory of Agrobiotechnology, College of Biological Sciences, China Agricultural \\ University, Beijing 100193, PR China \\ ${ }^{2}$ College of Life Science, Henan Agricultural University, Zhengzhou 450002, PR China \\ ${ }^{3}$ Departamento de Microbiología, Escuela Nacional de Ciencias Biológicas, Instituto Politécnico \\ Nacional, 11340 México DF, Mexico
}

Correspondence

Wen Xin Chen wenxin_chen@263.net
Species of the legume genus Albizia are commonly grown in temperate zones of Asia and Africa. There are about 150 species in the genus, and 17 of them can be found in southern China (Wu et al., 1988). The diversity of their microsymbionts has been characterized, revealing that a wide range of rhizobial species can establish effective symbioses with Albizia species (Wang et al., 2006).

†These authors contributed equally to this work.

Abbreviation: ITS, intergenic spacer.

The GenBank/EMBL/DDBJ accession numbers for the 16S rRNA gene, 16S-23S ITS, atpD and recA sequences of strains CCBAU $25010^{\top}$, CCBAU 25217 and CCBAU 41044 are respectively D0100063, EF070130 and AY395697 (16S rRNA gene), EU120729, EU120730 and DO352862 (16S-23S ITS), EU120726, EU120727 and DO310808 (atpD) and EU120732, EU120731 and EU034028 (recA). The accession number for the nodC sequence of strain CCBAU $25010^{\top}$ is EU120728.

Neighbour-joining trees based on ITS and atpD-recA sequences, SDSPAGE and BOX-PCR profiles of representative novel and reference strains and detailed DNA-DNA hybridization results are available as supplementary material with the online version of this paper.
Moreover, the novel species Mesorhizobium albiziae has been described (Wang et al., 2007), which was found to nodulate Albizia kalkora in a subtropical region of China. Kummerowia species are leguminous plants of medicinal value that originate from East Asia, and some of them have been introduced to other areas. Our previous data indicated that Kummerowia species were non-selective hosts for rhizobia and that they might nodulate with various bacteria in different regions (Lin et al., 2007, 2008). Rosewoods (species of Dalbergia L.), belonging to the subfamily Papilionoideae of the Leguminosae, are slowgrowing ornamental trees, some of which have medicinal value (Ito et al., 2003), and are usually used as hard timber in furniture production. They produce pharmaceutical substances that have antigiardial, antiallergic, antimicrobial and anticancer activities. There are about 150 species in the genus, which are distributed in tropical and subtropical areas of the world, and most of them form nodules (Allen \& Allen, 1981). It has been reported that bacterial strains isolated from nodules of Dalbergia species endemic to Madagascar belong to the Alphaproteobacteria and 
Betaproteobacteria (Rasolomampianina et al., 2005). A rhizobial strain isolated from Dalbergia lanceolaria was reported to produce indole acetic acid (Ghosh \& Basu, 2002). In China, 28 rosewood species have been recorded, mainly in the subtropical regions. The microsymbionts associated with Dalbergia species in Chinese soils have not been studied. In this study, a group of Dalbergia rhizobia are reported that showed close phylogenetic relationships with some strains isolated from Albizia (Wang et al., 2006) and Kummerowia (Lin et al., 2007), also grown in subtropical regions. Based upon a comparative study with multiple analyses, these strains were classified into a single group distinct from defined Rhizobium species.

Strains CCBAU $25010^{\mathrm{T}}$ and CCBAU 25116 were isolated from Albizia julibrissin grown in a temperate region of Shandong province on the east coast of China. Strains CCBAU 25217 and CCBAU 33126 were isolated from plants of two Kummerowia species. Strains from Dalbergia species were isolated near to the Changjiang river in Hunan province (Table 1). Bacterial strains were isolated from host root nodules following standard procedures (Vincent, 1970) and white, mucoid, translucent, convex colonies were observed on YMA medium (Vincent, 1970) at $28{ }^{\circ} \mathrm{C}$ after 3 days of incubation. Comparative analysis of $16 \mathrm{~S}$ rRNA gene sequences revealed that these strains belong to the genus Rhizobium. Cells of the strains were Gramnegative, non-spore-forming, short rods, similar to those of other Rhizobium species.

Comparison of 16S rRNA gene sequences is a powerful tool for deducing phylogenetic and evolutionary relationships among bacteria (Weisburg et al., 1991). Almost-complete $16 \mathrm{~S}$ rRNA gene sequences of three strains (CCBAU $25010^{\mathrm{T}}$, CCBAU 25217 and CCBAU 41044) were obtained following PCR amplification, as described by van Berkum et al. (1996). The sequences were aligned using CLUSTAL_X software (Thompson et al., 1997) with sequences held in GenBank. A 16S rRNA gene sequence-based phylogenetic tree (Fig. 1) was generated using the neighbour-joining method with programs of the software package MEGA 3.1 (Kumar et al., 2004) and bootstrapped with 1000 replications of each sequence. The strains from this study formed a distinct cluster within the genus Rhizobium (Fig. 1). The sequences of CCBAU $25010^{\mathrm{T}}$ and CCBAU 25217 were nearly identical, and they shared $99.5 \%$ sequence similarity with that of CCBAU 41044. The most similar sequence $(98.8 \%)$ from a defined species was that of Rhizobium sullae $\mathrm{IS}_{123^{\mathrm{T}}}$. 16S rRNA gene sequence similarities among the novel strains were greater than $99.5 \%$ and lower than $98.8 \%$ with other Rhizobium species. These data clearly demonstrated that these strains were members of a genomic species that differed from defined Rhizobium species.

All 13 novel strains could form nodules on their original hosts. Strains CCBAU $25010^{\mathrm{T}}$, CCBAU 25217 and CCBAU 41044, representing the novel Rhizobium group, were used for cross-nodulation tests. Seeds were treated with standard procedures for surface sterilization, germination and inoculation as described by Vincent (1970). Strains CCBAU $25010^{\mathrm{T}}$ and CCBAU 25217 were inoculated onto seeds of Medicago sativa, Glycine max and Phaseolus vulgaris. Strain CCBAU 41044 was inoculated onto seedlings of Medicago sativa, Robinia sp., Albizia sp., Glycine max, Phaseolus vulgaris and Glycyrrhiza sp., common leguminous plants grown in the regions where the rhizobia studied in this work were collected. Strain CCBAU 41044 was able to form nodules on Medicago sativa, but did not nodulate Robinia sp., Albizia sp., Glycine

Table 1. Strains used in this study

\begin{tabular}{|c|c|c|c|}
\hline Strain & Host plant & Geographical origin & Reference \\
\hline \multicolumn{4}{|l|}{ Rhizobium mesosinicum sp. nov. } \\
\hline CCBAU $25010^{\mathrm{T}}$, CCBAU 25116 & Albizia julibrissin & Shandong province, China & Wang et al. (2006) \\
\hline CCBAU 25217 & Kummerowia stipulacea & As above & Lin et al. (2007) \\
\hline CCBAU 33126 & Kummerowia striata & Jiangxi province, China & Lin et al. (2007) \\
\hline CCBAU 41044, CCBAU 41135 & Dalbergia balansae & Hunan province, China & \\
\hline CCBAU 41015, CCBAU 41026, CCBAU 41227 & Dalbergia hupeana & As above & \\
\hline CCBAU 41131 & Dalbergia dyeriana & As above & \\
\hline CCBAU 41176, CCBAU 41228 & Dalbergia mimosoides & As above & \\
\hline CCBAU 41226 & Dalbergia hancei & As above & \\
\hline \multicolumn{4}{|l|}{ Reference strains } \\
\hline R. sullae IS $123^{\mathrm{T}}$ & Hedysarum coronarium & Spain & Squartini et al. (2002) \\
\hline R. etli CFN $42^{\mathrm{T}}$ & Phaseolus vulgaris & Mexico & Segovia et al. (1993) \\
\hline R. leguminosarum bv. viceae USDA $2370^{\mathrm{T}}$ & Pisum sativum & USA & Jordan (1984) \\
\hline R. tropici CFN $299^{\mathrm{T}}$ & Phaseolus vulgaris & Brazil & Martínez-Romero et al. (1991) \\
\hline R. gallicum USDA $2918^{\mathrm{T}}$ & Phaseolus vulgaris & France & Amarger et al. (1997) \\
\hline R. yanglingense CCBAU $71623^{\mathrm{T}}$ & Gueldenstaedtia multiflora & Gansu, China & Tan et al. (2001) \\
\hline R. mongolense USDA $1844^{\mathrm{T}}$ & Meliloti luthenica & Inner Mongolia & van Berkum et al. (1998) \\
\hline R. indigoferae CCBAU $71042^{\mathrm{T}}$ & Indigofera amblyantha & Shaanxi, China & Wei et al. (2002) \\
\hline
\end{tabular}




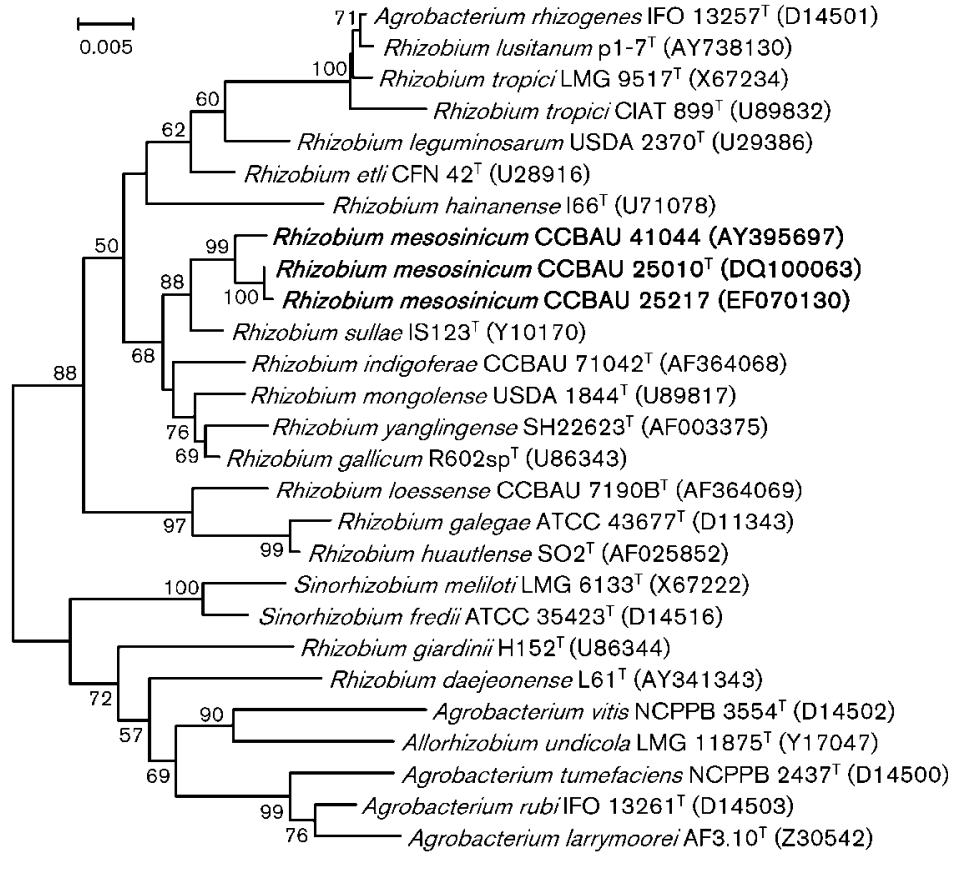

Fig. 1. Neighbour-joining tree of nearly fulllength 16S rRNA gene sequences showing the phylogenetic relationships of Rhizobium mesosinicum sp. nov. strains CCBAU $25010^{\top}$, CCBAU 25217 and CCBAU 41044 and related species in the genus. Bootstrap values obtained from 100 pseudoreplicates are provided at the corresponding nodes. Bar, 0.5\% nucleotide substitution. Strain CCBAU 41044 represents another eight rhizobial strains from Dalbergia species that had almost identical 16S rRNA gene sequences (GenBank accession numbers DQ310796-DQ310798, DQ310800, DQ310802, DQ310803, DQ485277 and DQ485278). max, Phaseolus vulgaris or Glycyrrhiza sp. Neither strain CCBAU $25010^{\mathrm{T}}$ nor strain CCBAU 25217 could nodulate Medicago sativa, Glycine max or Phaseolus vulgaris within 1 month of inoculation. To study the presence of symbiotic genes, a partial nodC fragment (800 bp) was amplified from strain $\mathrm{CCBAU} 25010^{\mathrm{T}}$ with primers $\mathrm{CF}\left(5^{\prime}\right.$ ATAGCAGCGATACGCCGTTCCTC-3') and CV (5'TGCGACCATCAGTTATGTCCACCAG-3') based on the nodC sequence of Rhizobium tropici. PCR conditions were as follows: preheating at $95{ }^{\circ} \mathrm{C}$ for $5 \mathrm{~min}$ followed by 30 cycles of denaturing at $91{ }^{\circ} \mathrm{C}$ for $1 \mathrm{~min}$, annealing at $55{ }^{\circ} \mathrm{C}$ for $45 \mathrm{~s}$ and extension at $72{ }^{\circ} \mathrm{C}$ for $1 \mathrm{~min}$, with a final extension at $72{ }^{\circ} \mathrm{C}$ for $6 \mathrm{~min}$. Attempts to amplify nodC or nifH gene fragments from other novel strains failed, despite using several primer pairs. The same primers used for amplification were used for nodC gene sequencing. The sequence of the nodC gene fragment amplified from CCBAU $25010^{\mathrm{T}}$ was $100 \%$ identical to that of $R$. tropici CFN 299 (Martínez-Romero et al., 1991).

Whole-cell soluble-protein SDS-PAGE (Tan et al., 1999) and BOX-PCR genomic fingerprinting (Vandamme et al., 2002; Nick et al., 1999) were utilized to identify differences between the novel strains and Rhizobium species and to investigate the diversity amongst the novel strains. Of the strains isolated from Dalbergia species, we used strain CCBAU 41044 only, since the profiles of these strains were identical. SDS-PAGE profiles showed similar protein profiles (Supplementary Fig. S1, available in IJSEM Online; compare lanes 1-4 and 12), with a few differences in the region covering $24-36 \mathrm{kDa}$, but the profiles of the novel strains were clearly different from those of $R$. sullae $\mathrm{IS}_{123^{\mathrm{T}}}$ (lane 5) and Rhizobium leguminosarum USDA $2370^{\mathrm{T}}$ (lane 6). The diversity within the species was reflected by BOX-PCR (Supplementary Fig. S2). Three fingerprint types were apparent (compare lanes 1-4). The fingerprints of strains CCBAU $25010^{\mathrm{T}}$ (lane 1) and CCBAU 25116 (lane 2) were nearly identical, suggesting that they probably represent the same bacterial clone, and they resemble the fingerprint type of CCBAU 41044 (lane 8).

A $1 \mathrm{~kb}$ fragment of the 16S-23S rRNA gene intergenic spacer (ITS) was amplified from strains CCBAU $25010^{\mathrm{T}}$, CCBAU 25217 and CCBAU 41044; they showed close relationships in a phylogenetic tree (Supplementary Fig. S3a). The ITS sequence of strain CCBAU 25010 ${ }^{\mathrm{T}}$ was similar to that of CCBAU 25217 (98\% similarity), and they showed 93.1 and $93.4 \%$ identity to that of CCBAU 41044. The ITS sequences of these three strains had $91.5 \%$ similarity with that of $R$. etli CFN $42^{\mathrm{T}}$ and $87.2 \%$ with that of $R$. leguminosarum LMG $14904^{\mathrm{T}}$. The ITS sequence similarity between these three strains and other Rhizobium species was lower than $88.6 \%$. Phylogenetic relationships estimated from ITS sequences (Supplementary Fig. S3a) differed little from those revealed by the sequence of the 16S rRNA gene. Previously work has shown that ITS sequences are more diverse than 16S rRNA gene sequences among Bradyrhizobium isolates (Willems et al., 2001). According to Kwon et al. (2005), phylogenetic analysis based on 16S rRNA gene and ITS region sequences showed remarkable heterogeneity amongst rhizobia. It had been reported that phylogenies based on the atpD and $\operatorname{rec} A$ genes were in good agreement with those based on the $16 \mathrm{~S}$ rRNA gene (Gaunt et al., 2001). However, in our study, the phylogeny based on concatenated atpD and $r e c A$ sequences was not congruent with that of the 16S rRNA gene (Supplementary Fig. S3b), but was congruent with the ITS phylogeny (Supplementary Fig. S3a). The concatenated 
atpD-recA sequence of CCBAU $25010^{\mathrm{T}}$ was related to those of CCBAU 25217 and CCBAU 41044 (95.6 and 92.4\% similarity, respectively). Sequence identities were lower than $91 \%$ with other Rhizobium species, and the novel strains formed a distinct branch close to $R$. tropici.

Physiological and biochemical characters were tested using conventional methods (Sneath \& Sokal, 1962). Utilization of 45 carbon and 13 nitrogen sources was determined as described by Chen et al. (1988). Resistance to antibiotics was tested by using final concentrations of 5, 50 and $100 \mu \mathrm{g} \mathrm{ml}^{-1}$ of kanamycin, ampicillin, erythromycin, streptomycin, gentamicin, chloromycin and neomycin on YMA medium (Vincent, 1970). Tolerance of $\mathrm{NaCl}$ was measured on TY (tryptone-yeast extract) medium containing $\mathrm{NaCl}$ at concentrations of $1,2,3,4$ and $5 \%(\mathrm{w} / \mathrm{v})$. The $\mathrm{pH}$ range for growth was studied between $\mathrm{pH} 4.0$ and 12.0 in the same medium. Growth at 37 and $60{ }^{\circ} \mathrm{C}$ on YMA medium and at $28{ }^{\circ} \mathrm{C}$ on Luria-Bertani (LB) medium was also tested with reference strains. Some phenotypic characteristics of the novel strains in comparison with several Rhizobium type strains are shown in Table 2. It should be noted that few features differentiate these strains from other Rhizobium species; strain CCBAU $25010^{\mathrm{T}}$ assimilated gluconate, malonate and D-ribose as carbon sources, was resistant to several of the tested antibiotics and grew at $\mathrm{pH}$ 4.0.

Table 2. Characteristics of representative novel strains and type strains of related Rhizobium species

Strains: 1, CCBAU $25010^{\mathrm{T}}$; 2, CCBAU 25217; 3, CCBAU 41044; 4, $R$. leguminosarum USDA $2370^{\mathrm{T}}$ (data from Drouin et al., 1996); 5, $R$. sullae $\mathrm{IS}_{2} 23^{\mathrm{T}}$ (Squartini et al., 2002); 6, R. tropici CFN 299 (this study); 7, R. mongolense USDA $1844^{\mathrm{T}}$ (van Berkum et al., 1998); 8, $R$. yanglingense CCBAU $71623^{\mathrm{T}}$ (Tan et al., 2001); 9, R. gallicum R602sp ${ }^{\mathrm{T}}$ (Amarger et al., 1997). +, Positive; (+), weakly positive; -, negative; ND, no data available.

\begin{tabular}{|lccccccccc|}
\hline Characteristic & $\mathbf{1}$ & $\mathbf{2}$ & $\mathbf{3}$ & $\mathbf{4}$ & $\mathbf{5}$ & $\mathbf{6}$ & $\mathbf{7}$ & $\mathbf{8}$ & $\mathbf{9}$ \\
\hline Assimilation of: & & & & & & & & & \\
Gluconate & + & $(+)$ & - & - & - & - & - & - & - \\
Malonate & + & - & - & - & - & - & - & - & - \\
Inulin & + & + & + & - & + & - & - & $(+)$ & - \\
Xylose & + & + & + & + & - & + & - & - & - \\
D-Ribose & + & + & + & - & - & + & - & - & - \\
Tartrate & $(+)$ & + & - & + & + & - & - & + & - \\
Growth at/in: & & & & & & & & & \\
$3 \%$ NaCl & - & - & - & - & - & - & + & - & - \\
pH 4.0 & + & + & - & - & - & - & $(+)$ & - & - \\
pH 10.0 & + & + & + & + & + & - & + & - & - \\
$37{ }^{\circ} \mathrm{C}$ & + & + & + & - & - & + & + & + & + \\
LB medium & + & + & + & + & + & - & + & - & - \\
Resistance to: & & & & & & & & & \\
Kanamycin & + & + & - & - & - & - & - & - & - \\
Ampicillin & + & + & + & + & + & + & - & $\mathrm{ND}$ & $\mathrm{ND}$ \\
Erythromycin & + & + & + & - & - & - & $\mathrm{ND}$ & $(+)$ & $\mathrm{ND}$ \\
Streptomycin & + & - & - & - & $\mathrm{ND}$ & - & - & $\mathrm{ND}$ & + \\
\hline
\end{tabular}

DNA base composition $(\mathrm{G}+\mathrm{C}$ content $)$ was determined spectrophotometrically as described by Marmur \& Doty (1962). The $\mathrm{G}+\mathrm{C}$ content for strain CCBAU $25010^{\mathrm{T}}$ was $61.8 \mathrm{~mol} \%$, which falls within the range of values reported for recognized Rhizobium species (59-64 mol\%; Jordan, 1984), supporting the suggestion that they belong to this genus. To estimated DNA-DNA relatedness, an initial renaturation rate method was used (De Ley et al., 1970). In view of the extremely high DNA-DNA hybridization values of the nine strains isolated from Dalbergia species, strain CCBAU 41044 was selected to perform DNA hybridization with CCBAU $25010^{\mathrm{T}}$ and CCBAU 25217. The level of DNA-DNA relatedness varied from 61.7 to $98.9 \%$ among these three strains. Strain CCBAU $25010^{\mathrm{T}}$ displayed 20.7$34.4 \%$ DNA-DNA relatedness with the type strains of a number of Rhizobium species (Supplementary Table S1).

Based on the genotypic, phenotypic and chemotaxonomic data presented in this study, we propose the classification of the 13 novel strains within a novel species of Rhizobium, for which the name Rhizobium mesosinicum sp. nov. is proposed.

\section{Description of Rhizobium mesosinicum sp. nov.}

Rhizobium mesosinicum (me.so.si'ni.cum. Gr. pref. meso central; N.L. neut. adj. sinicum belonging to China; N.L. neut. adj. mesosinicum of central China, referring to the location of isolation of the first strains).

Gram-negative, aerobic, non-spore-forming, motile rods $(0.5-0.7 \times 1.5-2.1 \mu \mathrm{m})$. Colonies are circular, creamcoloured, semi-translucent and $2-4 \mathrm{~mm}$ in diameter after 3 days of incubation at $28{ }^{\circ} \mathrm{C}$ on YMA medium. Tests for catalase, oxidase and urease activity are positive. No reduction of nitrate to nitrite. Optimum growth at 25$30{ }^{\circ} \mathrm{C}$; growth is observed at $37^{\circ} \mathrm{C}$. Optimum growth at $\mathrm{pH} 6-8$; can grow at $\mathrm{pH} 4-10$. Can grow at $2 \% \mathrm{NaCl}$ and on LB medium. No growth in medium containing adipate, malonate, inulin, melibiose, acetate, hippurate, sorbitol, starch, syringate, tartrate, vanillate, DL-arginine, DL-asparagine, L-glycine, methionine, L-threonine or D-glutamine. Does not hydrolyse starch, gelatin, casein, Tween 80 or DNA. Growth on Voges-Proskauer, methyl red test and indole production are negative. Cells are resistant to ( $\mu \mathrm{g}$ $\mathrm{ml}^{-1}$ ) ampicillin (100), erythromycin (100), kanamycin (50), streptomycin (100) and bacitracin (300), but susceptible to chloromycin (25), neomycin (10) and gentamicin (25). The G $+\mathrm{C}$ content of the type strain is $61.8 \mathrm{~mol} \%$.

The type strain, CCBAU $25010^{\mathrm{T}}\left(=\mathrm{LMG} 24135^{\mathrm{T}}=\mathrm{JCM}\right.$ $\left.14777^{\mathrm{T}}\right)$, was isolated from root nodules of Albizia julibrissin, growing in Shandong province, China.

\section{Acknowledgements}

This work was financed by the National Natural Science Foundation of China (project nos 30400001 and 30670001), the National Program for Basic S \& T Platform Construction (no. 2005DKA21201-10) and the National Basic Research Program of China (2006CB100206, 2006AA10A213). 


\section{References}

Allen, O. N. \& Allen, E. K. (1981). The Leguminosae: a Source Book of Characteristics, Uses and Nodulation. Madison, WI: University of Wisconsin Press.

Amarger, N., Macheret, V. \& Laguerre, G. (1997). Rhizobium gallicum sp. nov. and Rhizobium giardinii sp. nov., from Phaseolus vulgaris nodules. Int J Syst Bacteriol 47, 996-1006.

Chen, W. X., Yan, G. H. \& Li, J. L. (1988). Numerical taxonomic study of fast-growing soybean rhizobia and a proposal that Rhizobium fredii be assigned to Sinorhizobium gen. nov. Int J Syst Bacteriol 38, 392-397.

De Ley, J., Cattoir, H. \& Reynaerts, A. (1970). The quantitative measurement of DNA hybridization from renaturation rates. Eur $J$ Biochem 12, 133-142.

Drouin, P., Prévost, D. \& Antoun, H. (1996). Classification of bacteria nodulating Lathyrus japonicus and Lathyrus pratensis in northern Quebec as strains of Rhizobium leguminosarum biovar viciae. Int J Syst Bacteriol 46, 1016-1024.

Gaunt, M. W., Turner, S. L., Regottier-Gois, L. \& Lloyd-Macgilp, S. A. (2001). Phylogenies of atpD and recA support the small subunit rRNA-based classification of rhizobia. Int J Syst Evol Microbiol 51, 2037-2048.

Ghosh, A. C. \& Basu, P. S. (2002). Growth behaviour and bioproduction of indole acetic acid by a Rhizobium sp. isolated from root nodules of a leguminous tree Dalbergia lanceolaria. Indian J Exp Biol 40, 796-801.

Ito, C., Itoigawa, M., Kanematsu, T., Ruangrungsi, N., Higashihara, H., Tokuda, H., Nishino, H. \& Furukawa, H. (2003). New cinnamylphenols from Dalbergia species with cancer chemopreventive activity. $J$ Nat Prod 66, 1574-1579.

Jordan, D. C. (1984). Genus I. Rhizobium Frank 1889, $338^{\mathrm{AL}}$. In Bergey's Manual of Systematic Bacteriology, vol. 1, pp. 235-242. Edited by N. R. Krieg \& J. G. Holt. Baltimore: Williams \& Wilkins.

Kumar, S., Tamura, K. \& Nei, M. (2004). MEGA3: integrated software for molecular evolutionary genetics analysis and sequence alignment. Brief Bioinform 5, 150-163.

Kwon, S. W., Park, J. Y., Kim, J. S., Kang, J. W., Parker, M. A. \& Lee, J. B. (2005). Phylogenetic analysis of the genera Bradyrhizobium, Mesorhizobium, Rhizobium and Sinorhizobium on the basis of $16 \mathrm{~S}$ rRNA gene and internally transcribed spacer region sequences. Int $J$ Syst Evol Microbiol 55, 263-270.

Lin, D. X., Man, C. X., Wang, E. T. \& Chen, W. X. (2007). Diverse rhizobia that nodulate two species of Kummerowia in China. Arch Microbiol 188, 495-507.

Lin, D. X., Wang, E. T., Tang, H., Han, T. X., He, Y. R., Guan, S. H. \& Chen, W. X. (2008). Shinella kummerowiae sp. nov., a symbiotic bacterium isolated from root nodules of the herbal legume Kummerowia stipulacea. Int J Syst Evol Microbiol 58, 1409-1413.

Marmur, J. \& Doty, P. (1962). Determination of the base composition of deoxyribonucleic acid from its thermal denaturation temperature. $J$ Mol Biol 5, 109-118.

Martínez-Romero, E., Segovia, L., Mercante, F. M., Franco, A. A., Graham, P. \& Pardo, M. A. (1991). Rhizobium tropici, a novel species nodulating Phaseolus vulgaris $\mathrm{L}$. beans and Leucaena sp. trees. Int J Syst Bacteriol 41, 417-426.

Nick, G., Rasanen, L. A., De Lajudie, P., Gillis, M. \& Lindström, K. (1999). Genomic screening of rhizobia isolated from root nodules of tropical leguminous trees using DNA-DNA dot-blot hybridization and rep-PCR. Syst Appl Microbiol 22, 287-299.

Rasolomampianina, R., Bailly, X., Fetiarison, R., Rabevohitra, R., Béna, G., Ramaroson, L., Raherimandimby, M., Moulin, L., De Lajudie, P. \& other authors (2005). Nitrogen-fixing nodules from rose wood legume trees (Dalbergia spp.) endemic to Madagascar host seven different genera belonging to alpha- and beta-proteobacteria. Mol Ecol 14, 4135-4146.

Segovia, L., Young, J. P. W. \& Martínez-Romero, E. (1993). Reclassification of American Rhizobium leguminosarum biovar phaseoli type I strains as Rhizobium etli sp. nov. Int J Syst Bacteriol 43, 374-377.

Sneath, P. H. A. \& Sokal, R. R. (1962). Numerical taxonomy. Nature 193, 855-860.

Squartini, A., Struffi, P., Döring, H., Selenska-Pobell, S., Tola, E., Giacomini, A., Vendramin, E., Velázquez, E., Mateos, P. F. \& other authors (2002). Rhizobium sullae sp. nov. (formerly 'Rhizobium hedysari'), the root-nodule microsymbiont of Hedysarum coronarium L. Int J Syst Evol Microbiol 52, 1267-1276.

Tan, Z. Y., Wang, E. T., Peng, G. X., Zhu, M. E., Martínez-Romero, E. \& Chen, W. X. (1999). Characterization of bacteria isolated from wild legumes in the north-western regions of China. Int J Syst Bacteriol 49, 1457-1469.

Tan, Z. Y., Kan, F. L., Peng, G. X., Wang, E. T., Reinhold-Hurek, B. \& Chen, W. X. (2001). Rhizobium yanglingense sp. nov., isolated from arid and semi-arid regions in China. Int J Syst Evol Microbiol 51, 909914.

Thompson, J. D., Gibson, T. J., Plewniak, F., Jeanmougin, F. \& Higgins, D. G. (1997). The CLUSTAL_X windows interface: flexible strategies for multiple sequence alignment aided by quality analysis tools. Nucleic Acids Res 25, 4876-4882.

van Berkum, P., Beyene, D. \& Eardly, B. D. (1996). Phylogenetic relationships among Rhizobium species nodulating the common bean (Phaesolus vulgaris L.). Int J Syst Bacteriol 46, 240-244.

van Berkum, P., Beyene, D., Bao, G., Campbell, T. A. \& Eardly, B. D. (1998). Rhizobium mongolense sp. nov. is one of three rhizobial genotypes identified which nodulate and form nitrogen-fixing symbioses with Medicago ruthenica [(L.) Ledebour]. Int $J$ Syst Bacteriol 48, 13-22.

Vandamme, P., Goris, J., Chen, W. M., De Vos, P. \& Willems, A. (2002). Burkholderia tuberum sp. nov. and Burkholderia phymatum sp. nov., nodulate the roots of tropical legumes. Syst Appl Microbiol 25, 507-512.

Vincent, J. M. (1970). A Manual for the Practical Study of the RootNodule Bacteria. Oxford: Blackwell.

Wang, F. O., Zhang, Y. F., Wang, E. T. \& Chen, W. X. (2006). Characterization of rhizobia isolated from Albizia spp. in comparison with microsymbionts of Acacia spp. and Leucaena leucocephala grown in China. Syst Appl Microbiol 29, 502-517.

Wang, F. Q., Wang, E. T., Liu, J., Chen, O., Sui, X. H., Chen, W. F. \& Chen, W. X. (2007). Mesorhizobium albiziae sp. nov., a novel bacterium that nodulates Albizia kalkora in a subtropical region of China. Int J Syst Evol Microbiol 57, 1192-1199.

Wei, G. H., Wang, E. T., Tan, Z. Y., Zhu, M. E. \& Chen, W. X. (2002). Rhizobium indigoferae sp. nov. and Sinorhizobium kummerowiae sp. nov., respectively isolated from Indigofera spp. and Kummerowia stipulacea. Int J Syst Evol Microbiol 52, 2231-2239.

Weisburg, W. G., Barns, S. M., Pelletier, D. A. \& Lane, D. J. (1991). $16 \mathrm{~S}$ ribosomal DNA amplification for phylogenetic study. J Bacteriol 173, 697-703.

Willems, A., Coopman, R. \& Gillis, M. (2001). Comparison of sequence analysis of 16S-23S rDNA spacer regions, AFLP analysis and DNA-DNA hybridizations in Bradyrhizobium. Int $J$ Syst Evol Microbiol 51, 623-632.

Wu, T. L., Chen, P. Y., Wei, C. F., Chen, T. C., Hu, C. C., Cheng, H. C. \& Li, L. C. (1988). Flora Republicae Popularis Sinicae. Tomus 39, Angiospermae, Dicotyledoneae, Leguminosae (1). Beijing: Science Press. 